\title{
Investigating the Legal Foundations of the Rule of Pride to Analyze the Application and Concrete Examples of this Principle in Shiite Jurisprudence
}

\author{
Moradali Maleki ${ }^{1} \&$ Seyed Ebrahim Mousavi ${ }^{1}$ \\ ${ }^{1}$ Department of Law, Khorramabad Branch, Islamic Azad University, Khorramabad, Iran \\ Correspondence: Moradali Maleki, Department of Law, Khorramabad Branch, Islamic Azad University, \\ Khorramabad, Iran.
}

Received: June 12, 2016 Accepted: August 3, 2016 Online Published: October 30, 2016

doi:10.5539/jpl.v9n9p143 URL: http://dx.doi.org/10.5539/jpl.v9n9p143

\begin{abstract}
One of the factors affecting to create responsibility is deceiving, this means that if onedeceives someone else or someone fooled. For example, in marriage husband or wife deceived other or in sale contract the buyer deceived seller and deceiving in this case created the responsibility and liability, this type of responsibility is the liability in legal terms is called pride guarantee that is kind of guarantee in law enforcement and civil liability remembered it.In the study, we are tried toexamine proud guarantee in Iran's rights and Shiite. According to classic principles of responsibility to guarantee that pride be justified on the basis of the theory of fault, which are according to this theory, in addition to fault, other elements such as the arrival of harm must be proven and even limiting reference rightofproud those losses realized is not incompatible with the theory of fault.
\end{abstract}

Keywords: legal foundations, rule of pride, Shiite Jurisprudence

\section{Introduction}

One of the most important issues that the current situation gripping the country, claims for civil liabilitythat there was diversity in the law and the rules of civil liability is triggered, and one example of a responsibility "civil legal" means a person is deceptive. Iranian law stipulates not stated explicitly in this regard, but the lawyers responsible for "civil legal" under the principle of "pride" have examined.Despite the importance of the rule of pride in current law jurisdictions is especially practical procedure, sadly, so far as it is appropriate to rule on the legal aspect is not addressed.The rule of law in the books of fiqh rules, academic books, scientific theories scientists as well as ideas have been expressed emulation.Butthe legal framework of the rule ofpride not mentioned explicitly. However, Article 1036 of the Civil Code was the word of pride but also by virtue of the above material has been removed Reform Act of 08/14/1370.As mentioned, the base of pride among the legal rules that enter our statute law and its place in Iran's legal system. Therefore, it is clear that it is necessary to understand the origins and foundations of the rule of law will be studied.

Thisstudy aimed to investigate and rule of law principles to the analysis pride applications and concrete examples of the rule of law in jurisprudence on the one hand and on the other hand look at the legal system and laws of Iran.In this regard, the answer to the question in this article is also:

\subsection{Questions}

1. Is rule of proud only in cases of financial losses or spiritual losses that taxes such as legal aspects such as copyright is going on?

2. Is there rule of pride only between legal persons or between such as companies and the government?

\section{First Topic: The Meaning of Rule of Pride}

Literally the word of pride infinitive verb "Ghor" and literally means something to cause human ignorance and neglect (Mu'jam Al-vasit, p. 648). However, in terms of the definition given pride that: "When compensation due to the negligence and ignorance of the fact,reach the other person, that person is deceptive and transaction sponsor, in some cases, be void" (MakaremShirazi, 1411 AD. AH, p. 293).

In other words, practical when person do that deceived the others, and so, contemplate, it is a regular sponsor and 
must compensate for damages. The person who makes scammed by a "civil legal", the person deceived as "proud" and the rule "Rule of pride" called (MirfatahMaraghaee, 1297 AH, p. 323). It should be noted the above definition has said, "If someone's actionthat makes deceived others "and did not say that," If someone else fooling, "and this is why.Under the rule of pride because it is not necessary that the person have the intent to deceive, and may even deceive person is deceiving himself, but the amount that it is practical to do that through duped, is true example of pride.

Some have objected that the word "civil legal" is the name of the subject and means deceptive and so the intent is implicit in the word and the person cannot be said of non-intentional and non-herald " civil legal". The answer to that is a verb meaning to imply, there is not necessarily intentional and planned.That is why someone who sleeps on the third or laughs, saying "lying" or "smiling" despite how deliberately and intention not sleeping or laughing. The definition also brought pride: If someone else fooling anyone resulting in financial loss to cope with the loss of the person who cheated him (Shahabi, 1341 SB, p. 93). Others in the definition of pride have said:

The issuance of the work of someone else's losses and this loss is due to be cheated of it although it does not have the intention to deceive him and he deceived or ignorant or wrong (Bojnordi, 1969, p. 225). The most important argument that the rule of pride is whether it is necessary to apply to pride deceptive person to deceive or harm to convey to the proud and have deceived? Jurists, including:

Late Bojnordi believe that the intent requirement is not pride; so if you do that he may not be to deceive others, resulting in wasted money he is the guarantor of what to do, what action does not have the intent to deceive (Bojnordi, c are 1.1969, p. 233).

\section{Second Topic: Documentation Rule Pride}

Some jurists rule the pride of the branches of other rules, including the rule of no harm or know the base of the waste and causality but these rules no independent jurists among other legal rules considered and it will have detailed documentation.

\subsection{One: Narrative of the Prophet (PBUH) "The Deluded Could Refer to Someone Who Had Deceived Him"}

The famous hadith "the deluded could refer to someone who had deceived him". This hadith has been quoted by the researcher Thani on the sidelines of the Prophet (PBUH) has been assigned (TabatabaeiYazdi, 2008 AH, p. 179) .

Hadith phrases are quite expressive and signify that the rule is certain pride. Because it is clear that (refer) to demand compensation and damage through deception can it entered.In this respect, there is no difference, but what is controversial hadith refers to the document.Because a great number of scholars believe that, this tradition is unknown document and in any authentic hadith, books can be found in this tradition.The "titles" has said, "I have not encountered such a narrative books, news,although the words jurists also found that the statement of the immaculate quoted as saying it is about consensus and it requires consideration of the document. (HosseiniMaraghi, 1417 AH, p 324)

Sheikh Mohammad Hassan Najafi also in Jewel says, "... maybe Speech infallible that says" could be fooled refer to someone who had deceived him, "referring to the deceptive appearance of being legitimate" (Najafi, 1981, p. 145)

As you can see, Javaheri speech suggests that he is the owner of the sentence: "The deluded could refer to someone who had deceived him" knew as the hadith. However, some have said that it may be said of the documentary Javaheri it is well known among scholars as to what is expressed, (Because it was said that among jurists known as the hadith of the Prophet (pbuh)) and in fact, this was not the owner of the jewelry such as Hadith is stated (Mahzab, Bahar1979, p. 120). The result is that although this tradition by being famous, including evidence supporting the rule have taken pride but there are still fundamental problems of weak document that we cannot make a definitive statement to invoke our traditions. The following reasons for the weakness of researchers that comprehensively document the stories we explained exactly: "... Firstly, the Prophet in hadith books is not find in Shia, editor and researcher Javaher Al-Kalam writes: This tradition has been narrated from the Imams, but the story was the second researcher and his margin guidance in this hadith the Prophet (PBUH) ascribed but not right. As such, a legal rule is that the traditions of misrepresentation or otherwise taken.

After much searching this tradition, as chosen, and if it was found in the comprehensive book Jame Al-maqased including (a) for imams used the mirror to know that not for the Prophet (pbuh) will be the prophetic tradition. In any case, the problem remains that compensating for the weakness of the document if it is correct that attaches to 
compensating for weakness in the operative document is famous. Secondly, on the premise that basis, compensating for the weakness of the document in the form of a document that lives there, and expand the coverage of this story is no document to act jurists, be offset weak document. Third weakness will be the document when it is known practice is just to cite this story and there are other traditions, but since there are other narratives in this regard, it is unclear what action is to invoke companions. Therefore, mursalacannot be considered evidence of pride rule.

Third weakness will be the document when it is known practice is just to cite this story and other hadiths does not work, but because there are other narratives on the subject, people act based on which is unclear. So mursala cannot be considered evidence Rule ( Rahmani, Summer 1376, pp. 175 and 176).

\subsection{Second Rationalists}

Base of rationalists is the methods and manner of the wise, wise words, if practical approve and accept the acceptance that it is correct operation, and such approval may as proof of its action. Here are the order of the wise men of understanding this is definitely confirmed that if a person through other actions in any way the right to see cheated and losses for loss or damage which is suffered. It refers to the person who would have been deceived. In addition, this is a reason of pride to prove the rule. However, it could imply that the wise should not be rejected by the legislator called the legislator has not been rejected and revulsion.

The reason is that they have no objection to the wise approach is because labial and in cases of doubt as to doubt the ignorance and lack of intention of the pride, As pride is true or not, we cannot invoke this rule. Also, if you doubt that, if the benefit proud, whether pride is true or not? Open this rule cannot be invoked (Rahmani, Summer 1376, pp. 177). We should answer this objection goes over the details and examples of pride, so in these cases raised doubts about the issue. While the meaning of the rule of pride indicates wise and objective proof of principle, are not the details. In fact, no such objection can be raised for other reasons, if this principle cannot be expected to demonstrate the principle of the reasons and the pride that rule should be established in each particular case and according to the circumstances and customs of each community with a view to explaining specific examples of it. The result is that wise can be safely cited among the reasons supporting the principle of pride, but as late Bojnordi believe: one could say that the strongest and most perfect wise because, among other reasons, on the authority of a regulation of pride (Bojnordi, $1413 \mathrm{AH}$, p. 227)

\subsection{Third: Consensus and Students}

"Consensus is the consensus of the people who happen to be infallible discoverer of the vote, the matter of religious affairs" (Mohammadi, 2008, p. 175. Consensus has two kind, movable and students. The consensus is that the mujtahid who is trying to investigate the issue and there is consensus through quotes other scholars who are reliable and just be informed. Students also consensus is that the priest with opinions and fatwas of the scholars place them on other issues - although with the help of evidence acquired (Bojnordi, $1413 \mathrm{AH}, \mathrm{p} .227$ ) The consensus here is that Shiite scholars agree that the proud can refer to the civil legal. The issue here is of course also the premise that a "wise" has mentioned.This means that if the liability is fixed glamorous be ignorant or not?

But also because people hear such a conception and thus believes he has heart and another man praise due to the heavy dowry to the woman to marry and later married realize that she does not have any of the traits. In this case, the man could not be fooled by virtue of the rule of pride to see the deceiver?

Obviously,these cases as the result of a "wise" are described in the examples. Therefore, this objection is not reliable (Mahzab, $1413 \mathrm{AH}$, p. 121.)

More fundamental objection creates to the probative value of consensus in this regard. It is possible to say that the document is a consensus in the field of rule of waste and causality and so-called principled consensus to the rule of consensus is not pride. Note that "sometimes there books warrant issueand thus find all the jurists and the so-called consensus opinion that the verdict will be realized.However, sometimes it does not and there is no proof of warrant issue, however, there is consensus. The second type is more consensuses probative value in this case correctly it can be inferred among other reasons cited. The first reason is general agreement cannot be considered independently of other reasons, because the assumption is that the issue warrants book or tradition. This called consensus document "(Mohammadi, p. 187) In addition, studies consensus on such a difficult issue that was not molested all jurists, as Sheikh Ansari says: There is consensus on the issue of pride (Rahmani, Mohammad, p 176). The result is that if we believe that consensus is consensus document, it cannot rule on the validity of pride as an independent reason to know, but if the consensus, consensus its own means, in this case, it can be considered independent reason of pride for proving the validity of the rule. However, he 
certainly cannot be ruled and it seems that the likelihood of evidence being stronger consensus in this regard.

\subsection{Fourth: the Rule of Causality}

Causality rule of law and the legal rules and jurisprudence on various issues, including issues related to confiscation, retribution and blood money (the cause liability) has been proposed. Usually a waste of discussion after discussion in religious books also suggests causality. Waste and causality have a lot in common.

Causality from the root "cause" and literally means "sling", something which they do by resorting to it. (JafariLangroodi, 1967, p. 6)

In terms of jurisprudence and legal judgment in the event, the common source of damage to another (Salehi Rad, Winter 1378 , p. 43.) When a person is directly steward in other words, not mine waste, it provides waste arrangements and indirectly causes damage and loss of property or life or limb is another way of causality toggle. Such as personal object in the path of other people, and the other dealing damage to the object or damaged (Entezari, Issue 89, Summer 1391, p. 56.)

The point here is that the damage alleged and injured is "civil legal". While the steward was fooled by his loss but the longer (civil legal) has created, so therefore he must accept the principle of causality.The martyr Sani says: "If somewhere would come together and the steward, the steward sponsor because of the more powerful except in cases of duress and pride that guarantee the pride of the reluctance is deceptive and reluctantly, because in these two cases and the poor steward stronger. "So here, we see that the principle of causality as proof of liability at the base of pride considered. (Martyr Sani, 1410 AH, p. 226) Of course, some scholars have objected to it. They argue that the principle of causality argument implies that any liability is not the responsibility of haughty, while scholars have argued in this case as a proud sponsor on the front of the owner, but can refer to the civil legal after paying compensation. That is primarily the responsibility of haughty liability is fixed whereas in a place that is stronger view there is no guarantee rests with the poor steward (Mahzab, Ali, , p. 122.)Another problem in this field is to fulfill the terms of causality goes back guarantee. For the realization of the principle of causality is necessary that the steward is quite aimless and only in this state it could be argued that that is stronger view. As a result, at the base of the civil legal pride only when the liability is fixed that will absolutely be proud. It cannot be invoked in all cases.MirzaNaini the principle of causality, according to Criticisms, this rule is divided into two parts:

First swear, that the damage caused and not any other medium, such as a person do well and one in the fall and damage, damage directly caused by digging wells here has occurred, for this reason, the cause of the liability is fixed.The second type is that the act causing the damage, action taken by the supervisor, as they invite guests he currently works for the food belonging to others and guests ate food without the knowledge of this subject.Here is primarily the responsibility of the corrosive guarantee food (guests) is fixed but the causality and he may refer the caller to the person after suffering damage (Naini, 276).

The result is that "causality sometimes resulted in resulted in the realization of an act and sometimes liability. It seems forms of the past, the rule of causality, and causality is not meant a second meaning, can be one of the reasons pride rule, civil legalarrogant person because the person has caused work to be carried liability, although the technology is available and determination, and a measure of pride is at the base of the civil legal.So proud to do something that would guarantee and none of the bugs on the interpretation of pride rulehas not arrived because the rule was arrogant pride of the items will be included with the verb. In addition, guarantee, primarily on the length of the civil legal is also a proud sponsor and liability as applies not waste before the civil legal as wasteful because it is true, as true pride "(Rahmani Mohammad, pp. 179 and 180).

\section{Owner, Civil Legal and Proud Relationship}

If person deceive and cheated action damage personally to judge the question of the narrative: the proud must go to the civil legal.Yet another trick is that if arrogant pride and affected by third party property repeatedly makes the steward waste are you the proud owner of a guarantor against notand all the responsibility is directly aimed at deceiving? On the other hand, the owner is free to the snobbish (which is the steward wasted) and civil legal (which is) the client?However, the assumption in turn has recourse the cave or, in this case, only the owner is responsible steward?

The difference is especially important three points of view expressed in this regard, which are as follows:

A) The guarantor is proud to exempt because of poor stewardship and all the responsibility to the cave and the owner can directly go to the civil legal.This is attributed to the Shafi'i among the Shia believes it is known for certain (Najafi, 1266, vol 37, p 154). 
B) Civil legal and proud in front of the owner and the owner guaranteed are responsible to anyone who wants to can it. However, if the arrogant claim steward waste (haughty) because of pride, in turn, can be referred to the civil legal require and what is paid. However, you go straight to the civil legal, but will not be entitled to appear arrogant (Ibid .: p 57.58, p. 154).

C) the difference between the caverns of the mine waste was overtaken by conquest or somehow involved in it rather than wasting wastrel another role is not deceived.In this first part owner in refer to both its disposal.See proud of stewardship in reference to cave because of a history of domination and conquest is a waste.No one shall guarantee the detriment of the others. However, in the second case the owner is only entitled to proud steward, because the stronger view from the owner's steward (MohagheghDamad, 1994, p. 183)

\section{Legal Principles of the Rule of Pride}

\subsection{The Legal Basis}

The liability of pride and responsibility - in general - in two realms: Jurisprudence and law were studied. Now place each of them in the civil rights Iran.Comments forth in Jurisprudence, was introduced on the basis of liability pride. On this view, there is no explicit provision in the law but in $263 \mathrm{BC}$ "The owner, if the deal does not allow the customer the right to pry it is unwise for the price, and all compensation to pry the client vendor and if the world will be the only recourse for the price". According to the provisions of this article shall be regarded as the best examples of pride rule the phrase "all compensations" indicate that the buyer is entitled ignorant and arrogant see all compensation to pry to get the dealer whether it has used against them in court or interests, be wasted.This fits in with the "cheat" is appropriate.However, it can be said these provisions represent one of perspective in particular, gets not although with the "pride" in the base of pride. The above sentence is correct but can also be the basis of prejudicing the same must be accepted with the argument that the compensation listed are considered true loss although the buyer proud, compensation has been paid for benefits because he thought he was vindication that its use of benefits and compensation will be no change. (See, Bojnordi, 1413 AH, p. 156)

\subsection{Loss from Legal Perspective}

Some cited legal provisions of the article stated that the principle of limited recourse proud to have bear some losses to remain respectable (Katoozian, 1995, p. 96). This interpretation seems to be that they know the liability pride proud prejudicing while the article mentioned such a thing to happen and if we should say a little loosely based proud of its provisions, justify and demonstrated. In other words, by accepting the premise - proud of - no need for additional arguments, while the verdict will be based on the input current losses, the last argument is also necessary.The author has cited this example to illustrate his argument:

"If the house of the captured person to a person in search of the residence is rented and owner proverbial equal pay rent from him, this amount cannot be based on the rule of usurpers took pride" (Katoozian).It should be noted that this example previously discussed by Imam Khomeini and recourse is proud accepted not unless the damage is commonly referred to as the tenant interest and settlement is needed at home and if it was not by providing another way for the preparation of his action (Khomeini, $1421 \mathrm{AH}$, p. 337 and 352). But it seems that according referred to in this base- the accuracy is defined as the loss of compensation - referring to the usurpers have the right tenant because some fans as the "prejudicing" believe profit from property prevents the loss is not true (Ansari, $1418 \mathrm{AH}$, p. 147) It is true what the usurper return for rent and the tenant's deal use because of corruption and illicit trade - not - should be returned to the tenant (Katoozian, former).

However, it seems that this ruling does not prevent the compensation paid by proud owner; he is entitled to accept the usurper.Especially in view of the above example, the violator is sentenced to the hardest responsibilities (Al-GhasebBashaq Al-ahval).

This classic theoretical foundation of view is not explicitly mentioned in the legal texts but sometimes the lawyers' arguments, blame it deluding cited as the cause of responsibility.In the blink of an engagement without good cause the candidate stirred it because of the fault, is liable to compensate the damages (Safai, 1991, No. 21, $\mathrm{p}$ 32) Although if one of the candidates proposed marriage without good reason disrupt the opposite side or parents he trusts or other entities to the expenses of marriage and have been proud. However, that marriage should be responsible for damages stirred to cope".Described "proud" was mentioned in the legal analysis of its mandate, the abuse of the right and the fault is named (Safai, No. 22, pp. 32 and 33)One of the authors of pride when discussing guarantee conditions of jurisprudence, proud of fault on the part of the conditions mentioned (Katoozian, p. 159)While such a sense of pride in religious texts very rarely can be seen liability and this is indicative of their interpretation of the liability of pride. Knowledge and ignorance to modify and combine 
deceptive Comments written:

"If the fault is attributed to the seductive pride will be realized, though he had no intent to deceive is not aware of the truth .... However, if the fault cannot be attributed to him do not realize... "(Katoozian, p 160)

The phrase reflects is the guarantee to their opinion.

In addition, when talking about an illegitimate act as pillars to the current assignment of responsibility and obstacles, he talked about the pride to act as a barrier assignment in addition to the fault, in proportion to the problem, also raised the risk of loss.In other words, in cases where the fault is not the responsibility of deceiving the proud owner cannot absolve itself from the responsibility to know and in any case is liable, however, is the recourse to deception. However, if the fault to be involved in establishing responsibility and thereby committing the fault can be proud to know glory because of his ignorance, guilt has not been proven (Katoozian, former, pp. 277 and 278)

In summing up the site before, it seems that according to classic principles of responsibility, according to the theory of fault liability can be justified pride because according to this theory, in addition to fault, other elements, such proof shall be prejudicing and even limiting recourse to those losses realized he was proud- the followers of this analysis point of view is not incompatible with the theory of fault.

In addition to the classic view of the liability of pride, the choice theory about the legal basis - that is "proud of" - is harmony.

\section{Legal Sources of Pride Rule}

\subsection{Civil Law}

Civil Code as an important source of responsibility for the violence, bring it about. 307 is divided into four categories.

1) Usurped and what is confiscation order (Articles 308 to 327)

2) Waste (Articles 328 to 330)

3) Causality(Articles 331 to 335)

4) Vindication (Articles 335 and 336).

As well as other items do not fit under the previous categories have been predicted in this law, such as the management of non-interference property (d 306), use undirected (illegitimate) - is a common and unfair play in particular, gets (in Articles 301 to 305), examples of the use of undirected (Articles 33: Agriculture with the grain and another 172: lost pets)

However, in the above-mentioned materials, the pride as the guarantee - independent or dependent is not addressed.This situation is also a legal transaction and explicitly, not schemes liability pride. However, it seems that in some instances the pride element involved, some of the provisions of this Act may be cited in connection with it.

\subsection{The Civil Liability Law}

Civil liability law in Article 9 has spoken openly about liability arising from deceit.This Article states: "The girl who acts or threats or abuse of under-handed tricks, now for illicit sex may be the perpetrator, in addition to material losses, claim losses seem spiritual". In this regard, we can say that according to the law, including Article 1 of the manifestations of pride and cunning, Article 9 is located in one of the examples of material that seems to express a legislator is of great importance.So are other instances of pride and cunning, are subject to the provisions of Article One for net oil importer moral or material loss in this matter - in any way - in case of fault, liable for damages introduced and was told in advance that it seems to lawyers, pride and deceit deemed example of fault.Thus, in the law, whereby no single remedy listed or special laws, particular attention will be and thus guarantee 'greater pride as an independent causal liability - is not affected by the legislators.

\section{The Islamic Penal Code}

In accordance with Article 647 IPC (suspended) "If any one of the couples before marriage to the false things such as having higher education, financial ability, social status, occupation and the particular, celibacy and so deceive and contract based on any of them occurs, the offender shall be sentenced to imprisonment from six months to two years".

\section{Conclusion}

With so much at stake, a summary of the results is expressed as follows: 
1. In accordance with meaning of pride the definitions provided by the literal is concluded when compensation under the oversight and ignorance of the fact, to reach the other person, The same person is deceptive and transaction sponsor, in some cases, be void.In other words, if you do that which deceived anyone else, and so, the victim, that person shall be liable in accordance with the rule and must compensate for damages.The person who makes scammed by a "civil legal", the person deceived as "proud" and this rule as a "rule of pride," called.

2. To rule of pridein religious texts and works of fiqh rules related to generally listed six reasons, which includetradition wise approach, consensus and students, the rule of causality, rule and special traditions. The results of each of these reasons are as follows:

But there are still fundamental problems of weak document that we cannot make a definitive statement to invoke our traditions. The second reason can be safely said that the wise among the reasons cited supporting the principle of pride but as late Bojnordi wise believe we can say that the strongest and most perfect because, among other reasons, on the authority of a regulation of pride. The third reason also came to the conclusion that if we believe that consensus is consensus document, it cannot rule on the validity of pride as an independent reason to know, but if the consensus, consensus its own means, then it can be considered independent reason of pride for proving the validity of the rule. However, certainly cannot be ruled and it seems that the likelihood of evidence being stronger consensus in this regard.

\section{References}

Bojnordi, M. H. (1413 AH). jurisprudential rule (Vol. 1, 2nd ed.). Qom, Institute of Esmailian Press.

Katoozian, N. (1995, December). civil rights, obligations out of the contract (liability compulsory) (1st ed.). Tehran University Press.

LangroodiJafari, M. J. (1967), terminology rights. IbnSina Publications.

Mahmoud, S. (2006). periods of Jurisprudence (3rd ed.). Tehran, Tehran University Press.

Mahzab, A. (1979, Spring). research in this Rule to cite cases in Jurisprudence. magazine articles and studies, (32-33).

Mohammadi, A. (1995). the rules of jurisprudence (2nd ed.). Tehran, Publication Yalda.

Mohammadi, A. (2008). understanding the principles of Islamic law, jurisprudence (13th ed.). Tehran University Press.

Rahmani, M. (1376). legal rules: Rule. Fiqh inmate magazine, (10).

Safai, S. H., \& Imami, A. (1991). Family Law (Vol. 1). Tehran University Press.

Salehi Rad, M. (1378, Winter). causality and its funds. Justice Law Journal, (28-29).

\section{Copyrights}

Copyright for this article is retained by the author(s), with first publication rights granted to the journal.

This is an open-access article distributed under the terms and conditions of the Creative Commons Attribution license (http://creativecommons.org/licenses/by/4.0/). 